\title{
Analisis Faktor-Faktor yang mempengaruhi Kinerja Keuangan Bank Umum Syariah yang terdaftar di Bursa Efek Indonesia (BEI) (Periode 2014-2016)
}

\author{
Hamdani $^{1}$, Nining Wahyuni ${ }^{2}$, Ali Amin ${ }^{3}$, Sulfitra ${ }^{4}$ \\ ${ }^{1}$ Dosen Prodi Manajemen Keuangan Sektor Publik (MKSP) Politeknik Kutaraja Banda Aceh \\ ${ }^{2}$ Alumni Fakultas Ekonomi Manajemen Universitas Muhammadiyah Aceh \\ ${ }^{3}$ Dosen Fakultas Ekonomi, Jurusan Akuntansi Universitas Muhammadiyah Aceh \\ ${ }^{4}$ Dosen Fakultas Ekonomi, Jurusan Manajemen Unversitas Muhammadiyah Aceh
}

\begin{abstract}
Abstrak. Penelitian ini diharapkan berpengarub terbadap Financing to Deposit Ratio (FDR), Capital Adequacy Ratio (CAR), Biaya Operasional Pendapatan Operasional (BOPO) terhadap Return on Asset (ROA) sebagai proksi Kinerja Keuangan perbankan syariah di Indonesia periode 2014- 2016. Populasi dalam penelitian ini adalah 11 bank syariah di Indonesia yang terdaftar di Bursa Efek Indonesia untuk periode tahun 2014-2016, dan sampel diperoleh sebanyak. 33 bentuk 11 bank dan 3 periode keuangan repo 2014-2016 dengan purposive sampling. Metode Analisis data menggunakan regresi linier berganda dengan Software SPSS versi 16.0 Hasil dari penelitian ini menunjukkan bahwa variabel FDR dan CAR tidak berpengarub signifikan terbadap ROA, sedangkan variabel BOPO memiliki pengaruh signifikan terbadap $\mathrm{ROA}$. Kemampuan prediktif dari ketiga variabel pada $\mathrm{ROA}$ sebesar 72,3\%, sedangkan sisanya dipengarubi oleh faktor lain yang tidak termasuk dalam model riset.
\end{abstract}

Kata kunci: Financial Performance, Return on Assets, Financing to Deposit Ratio, Capital Adequacy Ratio, $B O P O$

\begin{abstract}
This research is supposed the effect Financing to Deposit Ratio (FDR), Capital Adequacy Ratio (CAR), (BOPO) Operating Expenses to Operating Income to Return on Asset (ROA) as a proxy of the Financial Performance of Islamic banking in Indonesia period 2014- 2016. The population in this study was 11 Islamic Bank in Indonesia in asset listed on Bursa Efek Indonesia for the period years 2014-2016, and the sample is got as 33 form 11 banking and 3 periods financial report of 2014-2016 by purposive sampling method. The data analyses employed the use of multiple linear regression with Software SPSS version 16.0. The result from this study indicates that variable Financing to Deposit Ratio and Capital Adequacy Ratio has not significant influences on $\mathrm{ROA}$, while $B O P O$ variable has significant influences on $\mathrm{ROA}$. Predictive ability of the three variables on the $\mathrm{RO} A$ of $72,3 \%$, while the rest is influenced by other factors not included in the research model.
\end{abstract}

Keywords: Financial Performance, Return on Assets, Financing to Deposit Ratio, Capital Adequacy Ratio, $B O P O$ 


\section{Pendahuluan}

Saat ini perbankan di Indonesia merupakan salah satu lembaga keuangan yang berperan penting dalam perekonomian negara, hal ini dikarenakan perbankan merupakan salah satu sistem keuangan yang berfungsi sebagai financial intermediary yaitu lembaga yang mempunyai peranan sebagai perantara penyalur dana dari pihak yang mempunyai kelebihan dana kepada pihak-pihak yang membutuhkan dana (Wedantika, 2017:15).

Berkembangnya perekonomian di Indonesia tidak lepas dari peran sektor perbankan yang membantu kemajuan perekonomian tersebut. Bank merupakan salah satu lembaga otoritas keuangan yang membantu perkembangan perekonomian di suatu negara. Dalam pelaksanaan kegiatannya bank memerlukan dana, sehingga menuntut bank untuk dapat menghimpun dana dari berbagai pihak, ketika semakin banyak dana yang dimiliki oleh bank maka semakin baik kontribusi bank dalam menjalankan kegiatannya. Selain hal tersebut, bank mempunyai tujuan sebagai penunjang pembangunan nasional dalam rangka meningkatkan pertumbuhan ekonomi dan stabilitas nasional, meningkatkan pemerataan pembangunan, sehingga tercapainya peningkatan kemakmuran bagi masyarakat.

Dalam dunia perbankan terdapat perbankan konvensional dan perbankan syariah, yang menjadi perbedaan mendasar antara bank konvensional dan bank syariah adalah adanya larangan bunga dalam bank syariah sebagaimana sistem bunga yang dianut oleh bank konvensional, sehingga dalam kegiatan operasionalnya bank syariah menganut sistem bagi hasil. Perkembangan perbankan syariah di Indonesia hingga tahun 2018 terus mengalami peningkatan jika dibandingkan dengan tiga atau lima tahun sebelumnya. Berdasarkan data dari Otoritas Jasa Keuangan (2018) diperoleh data pertumbuhan Bank Umum Syariah yaitu bertambahnya jumlah Bank Umum Syariah (BUS) yang beroperasi di Indonesia saat ini sebanyak 13 bank yang awalnya hanya berjumlah 12 bank hingga tahun 2015, diikuti peningkatan jumlah Unit Usaha Syariah (UUS) menjadi 21 bank tahun 2018 dan jumlah Bank Perkreditan Rakyat Syariah (BPRS) sebanyak
163 ditahun 2015, naik menjadi 167 bank ditahun 2018. Meningkatnya pertumbuhan bank Umum Syariah di Indonesia dipastikan karena semakin membaiknya tingkat kinerja perbankan di Indonesia, meningkatnya kinerja perbankan tak lepas dari upaya atau minat masyarakat untuk terus menggunakan jasa perbankan yang menjadi bank kepercayaan mereka, terkhusus bagi nasabah atau pihak yang menanamkan modalnya pada bank dengan harapan mendapatkan kembali keuntungan. Sehingga dalam meningkatkan kinerja, tentu setiap bank memiliki cara tertentu untuk mempertahankan nasabahnya agar modal yang ditanamkan tidak berpindah kebank lainnya.

Berdasarkan hal tersebut sangat jelas bahwa modal bank merupakan hal utama dalam meningkatkan kinerja keuangan bank, sehingga bank dituntut untuk hati-hati dalam penggunaaan dananya. Jika bank tidak baik dalam pengelolaan dana atau modal maka berakibat buruk pada kinerja bank tersebut, dan dikarenakan juga oleh krisis ekonomi yang pernah terjadi di Indonesia membuat masyarakat menjadi lebih teliti dalam menilai kinerja perbankan, oleh karena itu bank harus bisa menunjukkan kinerja yang optimal bagi masyarakat dengan menjaga tingkat profitabilitas, karena dengan profitabilitas yang tinggi masyarakat akan memiliki kepercayaan terhadap bank tersebut.

Penilaian tingkat kinerja keuangan merupakan hal yang sangat penting bagi suatu perusahaan, tak terkecuali perusahaan perbankan. Kinerja keuangan bank juga memiliki implikasi penting bagi pertumbuhan ekonomi suatu negara yang dapat dilihat dari laporan keuangan. Prastowo (2015: 5) menyatakan "tujuan dari laporan keuangan yaitu untuk menyediakan infomasi yang berkaitan dengan posisi keuangan seperti keuntungan, risiko, fleksibilitas keuangan, dan kinerja operasional perusahaan yang dapat bermanfaat bagi sejumlah besar pemakai dalam pengambilan keputusan ekonomi”. Dari pengertian diatas laporan keuangan dapat diartikan sebagai suatu informasi yang berkaitan dengan kegiatan operasional bank yang dapat digunakan untuk memprediksi kinerja keuangan suatu bank dan dijadikan pedoman bagi para pihak yang bersangkutan seperti investor, kreditur, dan pemerintah. 
Dalam Peraturan Bank Indonesia Nomor 9/1/PBI/2007 tentang Sistem Penilaian Tingkat Kesehatan Bank Umum, kondisi kesehatan bank dan kinerja perbankan dapat dilihat dengan menggunakan pendekatan CAMELS (Capital, Asset, Management, Earning, Liquidity, dan Sensitivity Market Risk). Hasil pengukuran berdasarkan rasio tersebut diterapkan untuk menentukan kesehatan bank, yang dikategorikan sebagai berikut; sehat, cukup sehat, kurang sehat, dan tidak sehat. Analisis CAMELS yang berkaitan dengan tingkat kesehatan bank tujuannya adalah untuk mengetahui kondisi bank tersebut yang sesungguhnya apakah dalam keadaan sehat atau mungkin tidak sehat (Kasmir, 2004) dalam (Khalifaturo'fiah dan Nasution, 2016:44).

Dengan adanya peraturan Bank Indonesia yang telah diuraikan diatas dapat diketahui bahwa rasio keuangan merupakan salah satu faktor penting untuk menganalisa tingkat kinerja keuagan suatu perusahaan. Fahmi (2014:46) mengemukakan "bahwa rasio keuangan dan kinerja perusahaan memiliki hubungan yang erat, dimana rasio keuangan merupakan analisis yang menjelaskan berbagai hubungan dan indikator keuangan, yang digunakan untuk menunjukan kondisi keuangan dimasa lalu dan membantu menunjukan risiko dan peluang yang akan diperoleh dimasa depan". Analisa rasio dapat dilakukan dengan cara membandingkan rasio-rasio keuangan dari tahun-tahun yang lalu dengan tujuan dapat dilihat trend (kemungkinan) dari rasio-rasio perusahaan dalam periode tertentu.

Dari paparan diatas diketahui bahwa pengukuran tingkat kinerja keuangan bank dapat dilakukan dengan menganalisa rasio keuangan perusahaan. Adapun rasio keuangan yang digunakan dalam penelitian ini adalah rasio profitabilitas, likuiditas dan solvabilitas suatu bank. Rasio profitabilitas merupakan rasio yang menunjukkan kemampuan perusahaan dalam menghasilkan keuntungan (profit) selama periode tertentu dan juga bertujuan untuk mengukur tingkat efektifitas manajemen dalam menjalankan operasional kegiatannya (Fahmi, 2014:54). Oleh karena itu rasio profitabilitas merupakan indikator yang paling tepat dalam mengukur tingkat kinerja keuangan suatu perusahaan. Salah satu bentuk rasio profitabilitas yang dapat digunakan dalam mengukur tingkat kembalian keuntungan dari total keseluruhan dana (asset) perusahaan adalah Return on Asset (ROA). Kartikasari dan Wahyuati (2014) mengemukakan bahwa ROA digunakan untuk mengukur kemampuan manajemen dalam memperoleh keuntungan (laba) secara keseluruhan, semakin besar ROA suatu bank, semakin besar pula tingkat keuntungan yang dicapai bank dan semakin baik pula posisi bank tersebut dari segi penggunaan asset. ROA merupakan rasio antara laba sebelum pajak terhadap total asset.

Selanjutnya rasio likuiditas merupakan rasio yang digunakan untuk mengukur kemampuan perusahaan dalam memenuhi kewajiban jangka pendeknya. Rasio ini penting karena kegagalan dalam membayar kewajiban dapat menyebabkan kebangkrutan perusahaan. Rasio yang paling tepat dalam mengukur rasio likuiditas yaitu rasio Loan to Deposit Ratio (LDR) atau Financing to Deposit Ratio (FDR) penggunaan pada bank syariah, merupakan rasio yang digunakan untuk mengetahui seberapa besar kemampuan bank dalam membayar kembali penarikan dana yang dilakukan deposan dengan pembiayaan yang telah diberikan sebagai sumber likuiditasnya. Semakin tinggi rasio tersebut memberikan indikasi bahwa semakin rendahnya kemampuan likuiditas bank yang bersangkutan sehingga memungkinan suatu bank dalam kondisi bermasalah akan semakin besar, dan kinerja keuangan bankpun akan menurun.

Berikutnya rasio solvabilitas merupakan rasio yang mampu menunjukkan kemampuan perusahaan untuk memenuhi kewajibannya dalam rangka memperoleh keuntungan dan mampu melunasi kewajibannya apabila perusahaan tersebut dilikuidasi baik keuangan jangka pendek maupun jangka panjang. Rasio yang dapat digunakan dalam rasio solvabilitas atau rasio permodalan yaitu Capital Adequacy Ratio (CAR). Rasio ini diperoleh dari membagi total modal dengan ATMR. Dalam peraturan Bank Indonesia menyatakan bahwa besarnya CAR minimum harus $8 \%$. Jika rasio CAR sebuah bank dibawah $8 \%$ maka bank tersebut tidak mampu menyerap kerugian yang mungkin timbul dari kegiatan bank, maka hal itu 
berpengaruh pada kinerja keungan bank tersebut.

Adapun kemampuan bank dalam meningkatkan pendapatan dan menekan biaya dapat diukur dengan rasio BOPO, rasio ini digunakan untuk mengukur perbandingan biaya operasional terhadap pendapatan operasional yang diperoleh bank. Semakin kecil rasio BOPO berarti semakin efisien biaya operasional yang dikeluarkan bank yang bersangkutan maka kemungkinan suatu bank dalam kondisi bermasalah semakin kecil sehingga kinerja keuangan bank semakin baik. Berdasarkan data yang diperoleh dari Otoritas Jasa Keuangan $(\mathrm{OJK})$ terkait dengan perkembangan Rasio keuangan Bank Umum Syariah pada tahun 2014 - 2016. Data tersebut dapat dilihat pada tabel 1.1 berikut ini :

Tabel 1. Perkembangan Rasio Keuangan Bank Umum Syariah (Dalam Persentase).

\begin{tabular}{llll}
\hline Rasio & $\mathbf{2 0 1 4}$ & $\mathbf{2 0 1 5}$ & $\mathbf{2 0 1 6}$ \\
\hline FDR & 86,66 & 88,03 & 85,99 \\
CAR & 15,74 & 15,02 & 16,63 \\
ROA & 0,41 & 0,49 & 0,63 \\
BOPO & 96,97 & 97,01 & 96,22 \\
\hline
\end{tabular}

Sumber : Stastistik Perbankan Indonesia, 2017

Dari tabel 1 diatas terlihat perkembangan rasio keuangan yang dihitung dari rasio Return on Asset (ROA) terus mengalami perubahan fluktuatif setiap tahunnya, pada tahun 2014 total ROA sebesar $0,41 \%$, dan terus meningkat sebesar 0,14\% pada tahun 2015-2016 menjadi sebesar 0,63\% di tahun 2016. Semakin tinggi nilai ROA semakin baik pula tingkat profitabilitas yang diperoleh perusahaan karena tingkat kembalian yang semakin besar. Namun pada hasil ROA diatas tidak mengidentikasi kinerja keuangan yang baik karena tidak memenuhi standar ketentuan Bank Indonesia terhadap ROA yaitu $1,25 \%$.

Variabel kedua adalah FDR, rasio ini merupakan proksi dari rasio likuiditas. Pada tabel 1 diatas dapat dilihat bahwa nilai FDR mengalami peningkatan $1.37 \%$ dari tahun 2014-2015, dan menurun kembali sekitar 2.04\% menjadi $85.99 \%$ ditahun 2016. Seperti yang kita ketahui jika FDR mengalami peningkatan maka menunjukan bank mampu menyalurkan kredit yang tinggi sehingga ROA juga akan mengalami peningkatan, hal tersebut sejalan dengan penelitian Khalifaturo'fiah dan Nasution (2016:46) menyatakan bahwa FDR memiliki pengaruh yang positif terhadap ROA, semakin besar nilai FDR maka nilai ROA akan meningkat. Namun pada tabel 1 memperlihatkan hasil yang tidak sesuai dengan penelitian tersebut, pada saat FDR mengalami penurunan pada tahun 2016 ROA justru mengalami peningkatan.

Variabel selanjutnya adalah CAR, rasio ini merupakan proksi dari rasio kecukupan modal dengan perbandingan antara ATMR dengan modal bank perusahaan. Pada tabel 1 terlihat nilai CAR menurun sebesar $0,72 \%$ dari tahun 20142015 dan mengalami peningkatan kembali sebesar 1,61\% dengan nilai CAR sebesar 16,63\% ditahun 2016. Meskipun nilai CAR terus mengalami penurunan dan kenaikan, tetap membuat CAR masuk dalam kategori sangat sehat karena memenuhi standar maksimum ketentuan Bank Indonesia untuk CAR 12\% yang artinya modal bank mampu menyerap kerugiankerugian yang timbul dari kegiatan usaha bank sehingga kinerja keuangan bank semakin meningkat. Namun apabila nilai CAR terlalu tinggi mengidinkasikan bahwa modal tidak disalurkan dengan optimal sehingga asset akan menjadi besar, dengan begitu laba yang akan diperoleh bank akan mengalami penurunan.

Pada tabel 1 juga terlihat bahwa perkembangan CAR tidak berbanding lurus dengan hasil ROA yang terus mengalami peningkatan setiap tahunnya, sehingga hal itu tidak sesuai dengan teori yang menyatakan bahwa CAR berpengaruh positif terhadap ROA. CAR yang tinggi akan mengidentifikasi bahwa modal dapat didayagunakan dengan efektif, sehingga akan meningkatkan asset yang ada, sehingga akan menyebabkan kenaikan terhadap ROA (Tristiningtyas dan Mutaher, 2013).

Variabel terakhir adalah BOPO, dimana BOPO merupakan rasio efisiensi yang digunakan perbankan dalam menjalankan kegiatan operasionalnya, dari tabel 1 dapat dilihat bahwa rasio $\mathrm{BOPO}$ mengalami peningkatan dari tahun 2014-2015 sebesar 0,04\% dan mengalami penurunan kembali sebesar 0,79\% ditahun 2016. Dengan nilai BOPO yang terus mengalami peningkatan dan penurunan tidak membuat 
kinerja keuangan dikategorikan sehat karena nilai BOPO yang melewati batas maksimum 90\% dari tingkat kesehatan kinerja bank yang telah ditetapkan Bank Indonesia. Meningkatnya nilai BOPO menandakan bahwa pihak bank tidak dapat menekan biaya operasional dengan baik sehingga pada rasio ROA mengalami penurunan dan berpotensi akan terjadi kerugian pada bank tersebut. Namun nyatanya ketika rasio BOPO meningkat pada tahun 2015, nilai ROA justru ikut meningkat pada tahun 2015 dimana seharusnya ROA akan mengalami penurunan. Hal ini menyimpulkan adanya ketidaksesuaian dengan teori yang menyatakan bahwa BOPO memiliki pengaruh negatif terhadap ROA, sehingga semakin besar nilai BOPO akan berakibat turunnya nilai ROA (Ardiansyah dan Mawardi, 2017:10).

Berdasarkan pada fenomena dan teori yang telah dipaparkan diatas diketahui bahwa terdapat permasalahan yang membuat kinerja keuangan bank mengalami penurunan, sehingga mengakibatkan bank mengalami kerugian. Oleh karena itu peneliti tertarik untuk meneliti faktor dominan yang berpengaruh terhadap kinerja keuangan suatu bank. Penelitian ini terbatas pada faktor-faktor yang mempengaruhi Kinerja Keuangan Bank (ROA) yaitu FDR (Financing to Debt Ratio), CAR (Capital Adequacy Ratio), dan BOPO (Operating Expenses to Operating Income).

Berdasarkan dari uraian diatas, maka permasalahan dalam penelitian ini adanya temuan yang berbeda dari beberapa faktor yang mempengaruhi Return on Asset (ROA), serta dari data empiris adalah terjadi beberapa penurunan ROA, sehinggga standar ROA sebesar 1,5\% tidak dapat dicapai oleh sebagian bank pada periode 2014-2016

\section{Tinjauan Literatur}

Menurut Undang-Undang Nomor 7 Tahun 1992 tentang perbankan sebagaimana telah diubah dengan Undang-Undang RI No. 10 Tahun 1998 tentang perbankan mendefinisikan bahwa "bank sebagai badan usaha yang menghimpun dana dari masyarakat dalam bentuk simpanan dan menyalurkan kepada masyarakat dalam rangka meningkatkan taraf hidup rakyat banyak". Bank syariah dalam menjalankan usahanya menghimpun dana dari masyarakat dan menyalurkannya kembali dalam bentuk pembiayaan, bentuk keuntungan yang diberikan kepada deposan menggunakan sistem bagi hasil, dimana keuntungan dan kerugian ditanggung bersama sesuai dengan perjajian (akad).

Menurut Prof.G.M.Verryn Stuart (Putra, 2011) "Bank is a company who satisfied other people by giving a credit with the money they accept as a gambleto the other, eventhough they should supply the new money" (Bank merupakan sebuah badan usaha yang wujudnya memuaskan keperluan orang lain dengan memberikan kredit berupa uang yang diterimanya dari orang lain, baik dengan cara mengeluarkan uang baru kertas atau logam). Dari beberapa pengertian diatas, bank dapat diartikan sebagai badan usaha yang kegiatanya mengumpulkan uang dari masyarakat yang mempunyai kelebihan uang (surplus) dan menyalurkannya kembali kepada masyarakat yang kekurangan uang (defisit) dalam bentuk kredit atau pembiayaan yang bertujuan untuk menopang perekonomian masyarakat banyak.

\section{Laporan Keuangan Bank}

Menurut Fahmi (2014:22) dalam bukunya "Analisis Kinerja Keuangan" menyatakan "bahwa laporan keuangan merupakan suatu informasi yang menggambarkan kondisi suatu perusahaan, dimana selanjutnya itu akan menjadi suatu informasi yang menggambarkan tentang kinerja suatu perusahaan". Adapun tujuan laporan keuangan adalah untuk memberikan informasi tentang posisi keuangan, kinerja, perubahan ekuitas, arus kas dan informasi lainnya yang bermanfaat bagi pengguna laporan dalam rangka membuat keputusan ekonomi serta menunjukkan pertanggungjawaban manajemen atas penggunaan sumber daya yang dipercayakan kepada mereka (Surat Edaran BI No. 11/4/DPNP Tanggal 27 Januari 2009). Secara umum tujuan utama laporan keuangan memberikan informasi terkait dengan keadaan keuangan suatu perusahaan yang digunakan oleh pihak pemakai laporan keuangan dalam pengambilan suatu keputusan.

Harmono (2013:104) menyatakan “analisis laporan keuangan merupakan suatu alat analisis 
yang dapat digunakan pihak manajemen keuangan secara menyeluruh untuk mendeteksi tingkat kesehatan perusahaan, melalui analisis kondisi arus kas atau kinerja perusahaa baik bersifat parsial maupun secara menyeluruh". Adapun menurut Prastowo (2015:56) "analisis laporan keuangan merupakan suatu proses yang penuh pertimbangan dalam melakukan pengevaluasian terhadap posisi keuangan dan hasil kegiatan perusahaan dimasa sekarang dan masa lalu, dengan tujuan agar dapat memprediksi kemungkinan yang paling mungkin terjadi dalam meningkatkan kinerja perusahaan dimasa mendatang”.

\section{Kinerja Keuangan}

Kinerja dapat diartikan sebagai tolak ukur berhasil atau tidaknya perusahaan dalam menjalanakan kegiatannya. Selain itu tujuan utama dari penilaian kinerja adalah untuk mengevaluasi seberapa baik kinerja karyawan dalam mengerjakan pekerjaan yang dibandingkan pada satu standar tertentu, kemudian informasi tersebut dikomunikasikan kembali agar menjadi motivasi bagi karyawan untuk melakukan perbaikan dalam membantu perusahaan mencapai visi dan misi yang telah ditetapkan (Fahmi, 2015:65). Jadi, kinerja (performance) bank adalah gambaran mengenai prestasi kerja perusahaan atau kemampuan kerja perusahaan yang didukung oleh pihak menajemen dalam kegiatan operasional yang dijalankan.

Menurut Fahmi (2014:2) "kinerja keuangan adalah suatu analisis yang dilakukan untuk melihat pencapaian keberhasilan perusahaan dalam pengelolaaan organisasi tersebut secara keseluruhan yang disesuaikan pada aturanaturan pelaksanaan keuangan secara baik dan benar". Dari pendapat di atas dapat diartikan bahwa kinerja keuangan adalah suatu penilaian seberapa baik hasil yang dicapai oleh perusahaan dalam mencapai tujuan perekonomian, dimana tujuan perekonomian adalah untuk memaksimumkan kesejahteraan rakyat.

\section{Rasio Keuangan}

Prastowo (2015:64) menyatakan "bahwa rasio keuangan adalah rasio yang menggambarkan tentang kondisi keuangan perusahaan dengan mencari hubungan antar pos-pos yang ada dalam laporan keuangan". Penggunaan rasio keuangan akan menjelaskan dan memberikan gambaran tentang baik buruknya keadaan posisi keuangan perusahaan, dengan membandingkan rasio pada saat sekarang dengan rasio yang akan datang (Fahmi, 2014:53).

Putra (2015:80) menyatakan bahwa rasio keuangan dapat membantu manajemen mengidentifikasi beberapa kekuatan dan kelemahan keuangan perusahaan. Analisis rasio dapat diklasifikasikan ke dalam lima kelompok yaitu: (1) rasio Likuiditas, (2) rasio Solvabilitas, (3) rasio Rentabilitas atau Profitabilitas, (4) rasio Pemanfaatan Aktiva dan (5) rasio Kinerja Operasi. Dalam penelitian ini terdapat tiga jenis rasio keuangan keuangan bank yaitu, (1) rasio Profitabilitas, (2) rasio Likuiditas, dan (3) rasio Solvabilitas.

\section{Return on Assets (ROA)}

Tristiningtyas dan Mutaher (2013:132) mengemukakan "bahwa Return on Asset (ROA) merupakan salah satu indikator yang dijadikan sebagai dasar untuk pengukuran kinerja keuangan suatu perbankan, karena ROA digunakan untuk mengukur efektifitas dalam memanfaatkan aktiva yang dimiliki”. ROA adalah salah satu alat analisis yang digunakan untuk menganilisis profitabilitas, rasio ini mengukur antara laba sebelum pajak terhadap total asset. Semakin besar ROA suatu bank, menunjukan kinerja keuangan bank semakin baik, karena tingkat keuntungan semakin besar.

\section{Berdasarkan Surat Edaran BI No. 13/30 DPNP} tanggal 16 Desember 2011, ROA dapat diukur dengan perbandingan antara laba sebelum pajak terhadap total aset (total aktiva). Laba sebelum pajak merupakan laba bersih dari kegiatan operasional bank sebelum pajak, sedangkan total aset yang digunakan adalah jumlah keseluruhan dari aset yang dimiliki oleh bank bersangkutan. Berdasarkan surat edaran BI No. 13/24/DPNP Tanggal 25 Oktober 2011, Bank Indonesia menetapkan suatu bank akan dianggap sehat atau baik kinerja keuangannya apabila nilai ROA lebih dari $1.25 \%$. 


\section{Biaya Operasional Pendapatan Operasional (BOPO)}

Biaya Operasional Pendapatan Operasional (BOPO) sering disebut rasio efisiensi yang digunakan untuk mengukur kemampuan manajemen bank dalam mengendalikan biaya operasional terhadap pendapatan operasional atau BOPO juga sering disebut sebagai perbandingan antara total biaya operasional dengan total pendapatan operasional. Semakin kecil rasio BOPO menunjukkan semakin efisien bank dalam menjalankan aktivitas usahanya. Efisiensi operasi akan mempengaruhi kinerja bank, yakni untuk menunjukkan apakah bank telah menggunakan semua faktor produksinya dengan tepat, guna mencapai keberhasilan yang telah diharapkan (Khalifaturo'fiah dan Nasution, 2016:46). Semakin kecil rasio BOPO mengidentikasikan semakin efisiensi bank dalam menekan biaya operasional yang dikeluarkan bank, sehingga kemungkinan suatu bank dalam kondisi bermasalah semakin kecil dan kinerja keuangan bankpun semakin baik. Bank Indonesia menetapkan angka terbaik untuk rasio BOPO adalah dibawah 90\%, karena jika rasio BOPO melebihi 90\% hingga mendekati angka 100\% maka bank tersebut dapat dikategorikan tidak efisien dalam menjalankan kegiatan operasionalnya.

\section{Financing to Deposit Ratio (FDR)}

Menurut Widantika (2017:27) Financing to Deposit Ratio (FDR) merupakan rasio yang digunakan untuk mengukur tingkat likuiditas, dengan cara membandingkan antara pembiayaan yang disalurkan dengan total dana yang dihimpun dari masyarakat sehingga dapat diketahui kemampuan bank dalam membayar kewajiban jangka pendeknya. Besarnya jumlah pembiayaan yang disalurkan akan menentukan tingkat keuntungan bank. Jika bank tidak mampu memberikan pembiayaan dengan maksimal sementara dana yang terhimpun berjumlah besar maka akan menyebabkan kerugian pada bank.

Semakin tinggi FDR suatu bank, maka memberikan indikasi semakin baiknya tingkat likuiditas dan keutungan yang deperoleh bank tersebut dengan syarat tidak terjadinya penunggakan atau kredit macet terhadap dana yang disalurkan. Berdasarkan surat edaran BI No. 13/24/DPNP Tanggal 25 Oktober 2011, Bank Indonesia menetapkan bahwa batas aman dari FDR suatu Bank adalah sekitar 78\% - 100\%. Batas aman memberikan indikasi bahwa setiap FDR suatu bank berada dalam kategori sehat. Jika FDR suatu bank berada diatas batas aman, maka bank tersebut dapat dikatakan tidak sehat disegi liquiditasnya.

\section{Capital Adequacy Ratio (CAR)}

CAR adalah rasio yang memperlihatkan seberapa jauh seluruh aktiva bank yang mengandung resiko (kredit, penyertaan, surat berharga, tagihan pada bank lain) ikut dibiayai dari dana modal bank sendiri, disamping memperoleh dana-dana dari sumber di luar bank. Dengan kata lain CAR adalah rasio yang digunakan untuk mengukur kemampuan bank dalam mempetahankan modal dan mengontrol risiko-risiko yang dapat berpengaruh terhadap besarnya modal yang dimiliki bank. Tristiningtyas dan Mutaher (2013:133) menyatakan bahwa CAR yang tinggi akan memberikan kontribusi yang cukup besar bagi profitabilitas dan mengindikasikan bahwa bank tersebut mempunyai aset yang likuid dalam jangka panjang.

Tingginya rasio modal dapat melindungi deposan dan meningkatkan kepercayaan masyarakat kepada bank, dan pada akhirnya dapat meningkatkan pendapatan suatu bank. Ketentuan Bank Indonesia, dimana bank yang memiliki kinerja yang baik harus memenuhi kriteria CAR sebesar 8\%. Sehingga bank harus selalu menjaga rasio CAR agar selalu di atas $8 \%$. Jika rasio CAR bank dibawah $8 \%$ maka bank tersebut tidak mampu menyerap kerugian yang timbul dari kegiatan operasional bank.

\section{Metodologi Penelitian}

Teknik analisis pada penelitian ini menggunakan analisis regresi linier berganda. Regresi liner berganda dilakukan untuk mengetahui sejauh mana variabel bebas (independen) mempengaruhi variabel terikat (dependen). Hubungan fungsi antara satu variabel dependen dengan lebih dari satu variabel independen dapat dilakukan dengan analisis regresi linier berganda, dimana ROA sebagai variabel dependen 
sedangkan FDR, CAR, dan BOPO sebagai variabel independen. Analisis regresi linier berganda harus terbebas dari ketidaknormalan data, multikolinieritas, heteroskedastisitas, dan autokorelasi. Selain harus melalui uji asumsi klasik, analisis regresi berganda juga harus melalui uji hipotesis yang mencakup uji koefisien determinasi, uji signifikansi, dan uji signifikansi parameter individual (statistic $\mathrm{t}$ ). Adapun persamaan dari model regresi linier berganda yang digunakan adalah sebagai berikut:

\section{Analisa dan Pembahasan}

Berdasarkan hasil pengujian normalitas dan asumsi klasik, maka data memenuhi unsur-unsur tersebut. Dimana data berdistribusi normal dan terbebas dari persoalan autokorelasi, multikolonieritas, dan heteroskedastisitas. Sehingga analisis dapat dilanjutkan kejenjang berikutnya, yaitu analisis regresi dan pengujian goodness of fit. Analisis regresi dilakukan dengan menempatkan ROA sebagai variabel dependen, dan FDR, CAR, dan BOPO sebagai variabel

Tabel 2. Persamaan Regresi Linier Berganda Coefficients

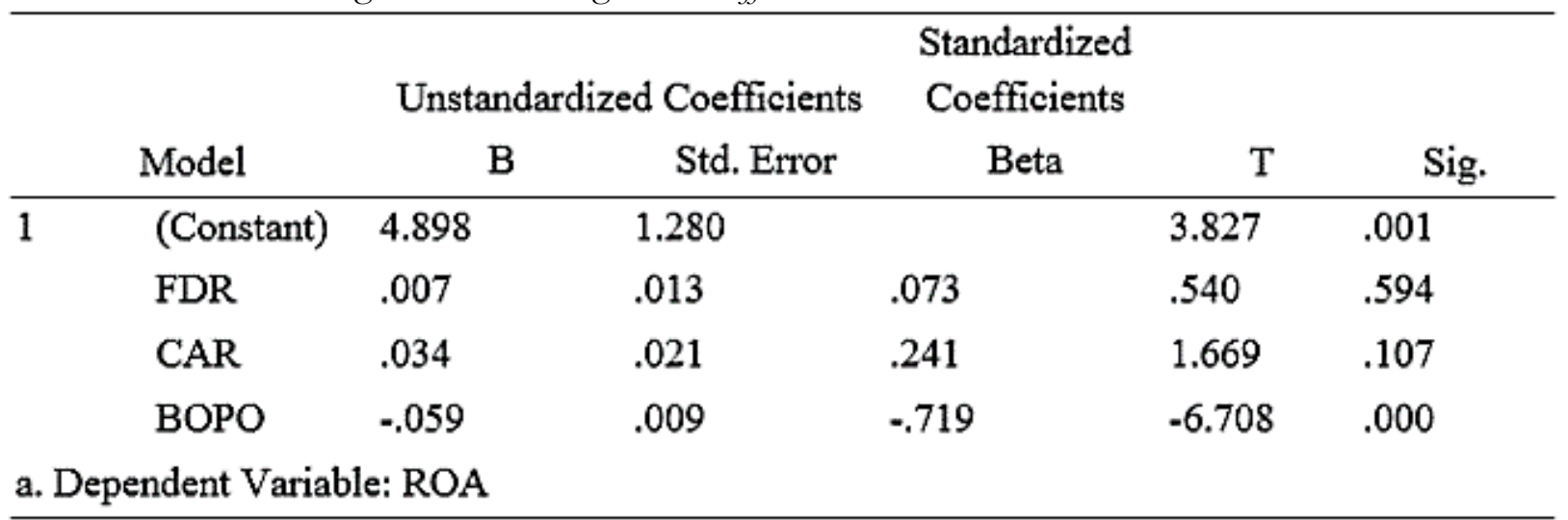

Sumber: Output SPSS 16.0, data sekunder yang diolah, 2018

$$
\mathbf{Y}=\alpha+\mathbf{B}_{1} \mathbf{X}_{1}+\mathbf{B}_{2} \mathbf{X}_{2}+\mathbf{B}_{3} \mathbf{X}_{3}+\mathbf{e}
$$

Dimana :

$$
\begin{aligned}
& \mathrm{Y}=\text { Kinerja Bank (Return on Asset) } \\
& \alpha \quad=\text { Konstanta } \\
& \mathrm{B}_{1} \mathrm{~B}_{2} \mathrm{~B}_{3} \quad=\text { Koefisien Regresi } X \\
& \mathrm{X}_{1} \quad=\text { Financing to Deposit } \\
& \text { Ratio (FDR) } \\
& \mathrm{X}_{2} \quad=\text { Capital Adequacy Ratio (CAR) } \\
& \mathrm{X}_{3} \quad=\text { Biaya Operasional } \\
& \text { Pendapatan Operasional } \\
& \text { (BOPO) } \\
& \text { e }=\text { error }
\end{aligned}
$$

Nilai koofisien regresi digunakan sebagai dasar analisis karena mengingat penelitian yang dilakukan bersifat fundamental method. Hal ini menyatakan jika koofisiens b bernilai positif $(+)$ maka akan memberi pengaruh searah antara variabel independen dengan variabel dependen. Setiap perubahan kenaikan pada variabel independen akan meningkatkan nilai dependen. Demikian pula sebaliknya, bila koofisien b bernilai negatif (-) maka terdapat pengaruh negatif pada kenaikan variabel independen akan mengakibatkan penurunan nilai variabel dependen. independen. Hasil analisis regresi sebagaimana ditunjukkan pada Tabel 2. Dari hasil perhitungan regresi linear berganda pada tabel 2 di atas, dapat diketahui hubungan antara variabel independen dan variabel dependen yang dapat dirumuskan dalam persamaan sebagai berikut:

$\mathrm{ROA}=4.898+0,007 \mathrm{FDR}+$ 0,034 CAR$0,059 \mathrm{BOPO}+\mathrm{e}$

Nilai konstan ini menunjukan apabila tidak ada variabel FDR, CAR, dan BOPO, maka nilai ROA sebesar 4.898. Besarnya koefisien FDR sebesar 0,007 menunjukkan bahwa adanya hubungan positif antara FDR dengan ROA, berarti bahwa setiap perubahan satuan pada FDR dengan asumsi variabel lainnya tetap, maka ROA akan mengalami kenaikan sebesar 0,007. Besarnya koefisien CAR sebesar 0,034 menunjukkan bahwa adanya hubungan positif antara CAR dengan ROA. Ini berarti bahwa setiap perubahan satuan pada CAR dengan asumsi variabel lainnya tetap, maka ROA akan mengalami kenaikan sebesar 0,034. Besarnya koefisien BOPO sebesar -0,059 menunjukkan bahwa adanya hubungan negatif antara BOPO dengan ROA. Ini berarti bahwa setiap perubahan satuan pada BOPO dengan asumsi variabel 
lainnya tetap, maka ROA akan mengalami penurunan sebesar - 0,059.

Pengujian model untuk menguji kesesuaian model (goodness of fit) dilakukan dengan menguji koefisien determinasi dan ANOVA. Koefisien determinasi untuk mengetahui nilai $R$-square dan ANOVA untuk mengetahui nilai $\mathrm{F}$ atau sig- $F$.

Koefisien determinasi digunakan untuk mengukur seberapa jauh kemampuan model dalam menerangkan variasi variabel independen. Hasil pengujian koefisien determinasi dapat dilihat pada Table 3 berikut ini:

Tabel 3. UJI R Model Summary.
Hasil uji ANOVA pada Tabel 4 dilakukan untuk mengetahui nilai $\mathrm{F}$ yang akan digunakan untuk menentukan apakah model regresi tersebut layak atau tidak digunakan. Tabel 4 diatas menunjukkan bahwa nilai signifikansi $0,000<$ 0,05 maka dapat disimpulkan bahwa semua variabel independen yaitu FDR, CAR dan BOPO berpengaruh signifikan secara simultan (bersama-sama) terhadap kinerja keuangan bank umum syariah yang diproksikan dengan Return on Assets (ROA).

\begin{tabular}{lll} 
Model & R & R Square \\
\hline 1 & $.867^{\mathrm{a}}$ & .752 \\
a. Predictors: (Constant), BOPO, FDR, CAR \\
b. Dependent Variable: ROA
\end{tabular}

Std. Error of the

Adjusted R Square Estimate

$.723 \quad .65422$

Sumber: Output SPSS 16.0, data sekunder yang diolah, 2018.

Tabel 4. Hasil Uji F ANOVA.

\begin{tabular}{|c|c|c|c|c|c|c|}
\hline & Model & $\begin{array}{l}\text { Sum of } \\
\text { Squares }\end{array}$ & Df & Mean Square & $\mathrm{F}$ & Sig. \\
\hline \multirow[t]{3}{*}{1} & Regression & 33.749 & 3 & 11.250 & 26.284 & $.000^{\mathrm{a}}$ \\
\hline & Residual & 11.128 & 26 & .428 & & \\
\hline & Total & 44.877 & 29 & & & \\
\hline \multicolumn{7}{|c|}{ a. Predictors: (Constant), BOPO, FDR, CAR } \\
\hline \multicolumn{7}{|c|}{ b. Dependent Variable: ROA } \\
\hline
\end{tabular}

Sumber: Output SPSS 16.0, data sekunder yang diolah, 2018.

Berdasarkan Tabel 3 diperoleh hasil Adjusted R Square terdapat angka sebesar 0,723 atau $72,3 \%$. Hal tersebut dapat menunjukan bahwa variabel independen (FDR, CAR, dan BOPO) pada penelitian ini dapat menjelaskan variabel dependen ROA sebesar $72,3 \%$ sedangkan sisanya $27,7 \%$ kinerja keuangan bank dijelaskan oleh faktor lain diluar penelitian ini, seperti (Inflasi, tingkat bunga, DPK, NPF) dan lain sebagainya. Nilai Standar Error of the Estimate (SEE) menunjukan nilai sebesar 0, 65422. Jika nilai SEE semakin kecil maka dapat membuat model regresi lebih tepat dalam mempredisksi variabel dependen (Ardiansyah dan Mawardi, 2017:8).

\section{Simpulan}

Berdasarkan hasil penelitian tersebut diatas, semua variabel independen yaitu Financing to Deposit Ratio (FDR), Capital Adequacy Ratio (CAR) dan Biaya Operasional Pendapatan Operasional (BOPO) secara bersama-sama mempunyai pengaruh terhadap variabel dependen yaitu Return on Asset (ROA) sebagai proksi dari kinerja keuangan bank. Implikasi praktis dalam penelitian ini dapat dijabarkan sebagai berikut :

1. Dengan melihat variabel Financing to Deposit Ratio (FDR), maka pihak manajemen dalam usahanya untuk meningkatkan Return on Asset (ROA) diharapkan mampu lebih 
efisien dalam menyalurkan dana kepada masyarakat dan mampu menjaga besarnya Financing to Deposit Ratio (FDR) antara 78\%$100 \%$ sesuai dengan standar yang digunakan oleh Bank Indonesia.

2. Dengan melihat variabel Capital Adequacy Ratio (CAR) maka pihak manajemen dalam usahanya untuk meningkatkan Return on Asset (ROA) diharapkan mampu mampu menyediakan dana (modal) untuk keperluan pengembangan usaha serta menampung kemungkinan risiko kerugian yang diakibatkan dalam operasional bank. Dengan kata lain, untuk meningkatkan Return on Asset (ROA) maka pihak manajemen harus meningkatkan Capital Adequacy Ratio (CAR). Sesuai dengan standar yang ditetapkan Bank of International Settlements (BIS) maka perusahaan perbankan (dalam hal ini bank devisa) wajib menyediakan modal minimum sebesar $8 \%$ dari ATMR. Semakin besar Capital Adequacy Ratio (CAR) suatu bank, maka semakin tinggi juga Return on Asset (ROA)-nya, karena semakin besar Capital Adequacy Ratio (CAR) maka semakin tinggi kemampuan permodalan bank dalam menjaga kemungkinan timbulnya risiko kerugian usahanya sehingga kinerja bank tersebut akan meningkat.

3. Dengan melihat variabel BOPO (Biaya Operasional/Pendapatan Operasional), maka pihak manajemen dalam usahanya untuk meningkatkan Return on Asset (ROA) diharapkan mampu menekan besarnya BOPO, sehingga biaya operasional yang dikeluarkan bank yang bersangkutan akan semakin efisien. Berdasarkan ketentuan Bank Indonesia, besarnya rasio BOPO yang normal yaitu dibawah $90 \%$, maka jika rasio BOPO suatu bank berada dibawah nilai tersebut dapat diartikan bahwa bank tersebut dikategorikan efisien dalam menjalankan kegiatan operasionalnya. Pergerakan rasio BOPO haruslah menjadi perhatian khusus agar perusahaannya selalu berada pada tingkat efisiensi yang bisa menghasilkan laba yang maksimal, sehingga kinerja yang dicapai akan selalu meningkat.

4. Berdasarkan hasil analisis rasio tersebut mengindikasikan bahwa menajemen bank perlu memperhatikan BOPO karena rasio keuangan bank tersebut merupakan variabel yang paling dominan dan konsisten dalam mempengaruhi penurunan nilai ROA. Sedangkan faktor yang mempengaruhi peningkatan ROA adalah FDR dan CAR

\section{Daftar Pustaka}

Ardiansyah, Rizki dan Mawardi, Wisnu. 2017. Analisis pengaruh capital adequacy ratio, loan to deposit ratio, bopo, dan net interest margin terhadap kinerja keuangan bank. Jurnal Manajemen dan Akutansi, Fakultas Ekonomika dan Bisnis Universitas Diponegoro. Vol.6 No. 4, hal 1-12, Edisi 2017.

Arikunto, Suharsimi. 2010. Prosedur Penelitian Suatu Pendekatan Praktek. Jakarta: Rineka Cipta.

Bank Indonesia. 2017. Laporan Keuangan Publikasi Bank. .www.bi. go.id. Diakses 28 Februari 2018.

Bungin, Burha. 2013. Metodeologi Penelitian Sosial dan Ekonomi. Jakarta : Kencanan Prenada Media Group.

Fahmi, Irham. 2014. Analisis Kinerja Keuangan. Bandung: Alfabeta.

Fahmi, Irham. 2015. Manajemen Kinerja Teori dan Aplikasi. Bandung: Alfabeta.

Ghozali, Imam. 2011. Aplikasi Analisis Multivariate Dengan Program IBM SPSS 19. Semarang: Universitas Diponegoro.

Harmono. 2013. Manajemen Keuangan. Jakarta: Bumi Aksara Kondisi.

Kartikasari, Meidita dan Wahyuati, Aniuek. 2014. Penilaian kinerja keuangan menggunakan analisis rasio pada bank mandiri di BEI. Jurnal Ilmu \& Riset Manajemen, Sekolah Tinggi Ilmu Ekonomi Indonesia (STIESIA). Vol. 3 No. 11.

Khalifaturo'fiah, Sholoikha Oktavi dan Nasution, Zubaidah. 2016. Analisis faktor-faktor yang mempengaruhi 
kinerja keuangan perbankan di indonesia. Jurnal Perbankan Syariah, STIE PERBANAS Surabaya. Vol.1 No. 2, Edisi November 2016.

Otoritas Jasa Keuangan. 2017. Statistik Perbankan Syariah. Otoritas Jasa Keuangan Republik Indonesia Departemen Perizinan dan Informasi Perbankan. Indonesia. Jakarta Pusat.

Otoritas Jasa Keuangan. 2018. Statistik Perbankan Syariah. Otoritas Jasa Keuangan Republik Indonesia Departemen Perizinan dan Informasi Perbankan. Indonesia. Jakarta Pusat.

Paulin, Okky. dan Wiryono, Sudarso Kaderi. 2015. Determinants of islamic bank's profitability in indonesia for 2009-2013. Journal Of Business And Management Vol. 4 No.1, hal. 175-185.

Prastowo, Dwi. 2015. Analisis Laporan Keuagan. Yogyakarta : Unit Penerbit dan Percetakan Sekolah Tinggi Ilmu Manajemen YKPN.

Putra, Ambika Pega Wiyas. 2011. Analisis Faktor-Faktor Yang Mempengaruhi Kinerja Keuangan Lembaga Perbankan Pada Bank Swasta Nasional Periode 2006-2009. Skripsi. Fakultas Ekonomi Universitas Diponegoro. Semarang. Tidak dipublikasikan.

Sejarah Bank. diakses pada tanggal 7 Agustus 2018 dari .www.brisyariah.co.id

Sejarah Bank. diakses pada tanggal 7 Agustus 2018 .bankvictoriasyariah.co.id.

Sejarah Bank. diakses pada tanggal 7 Agustus 2018 .www.bankmuamalat.co.id .

Sejarah Bank. diakses pada tanggal 7 Agustus 2018. www.bcasyariah.co.id.

Sejarah Bank. diakses pada tanggal 7 Agustus 2018.www.bankbjb.co.id
Sejarah Bank. diakses pada tanggal 7 Agustus 2018. www.sahamok.com/bank/daftarbank-syariah/

Sejarah Bank. diakses pada tanggal 7 Agustus 2018 .www.paninbanksyariah.co.id.

Sejarah Bank. diakses pada tanggal 7 Agustus 2018 .www.syariahbukopin.co.id.

Sejarah Bank. diakses pada tanggal 7 Agustus 2018 .www.bnisyariah.co.id

Sejarah Bank. diakses pada tanggal 7 Agustus 2018 .www.syariahmandiri.co.id.

Sejarah Bank. diakses pada tanggal 7 Agustus 2018 www.maybanksyariah.co.id.

Sugiyono. 2010. Metode Penelitian Pendidikan Pendekatan Kuantitatif,Kualitatif, Dan R \& D. Bandung: Alfabeta.

Surat Edaran Bank Indonesia No.13/24/DPNP Tanggal 25 Oktober 2011 tentang Tata Cara Penilaian Kesehatan Bank. Jakarta.

Surat Edaran Bank Indonesia, No. 11/4/DPNP Tanggal 27 Januari 2009 perihal Pelaksanaan Pedoman Akutansi Perbankan Indonesia (Revisi 2008). Jakarta.

Surat Edaran Bank Indonesia, No. 13/24/DPNP Tanggal 25 Oktober 2011 Perihal Tata Cara Penilaian Kesehatan Bank. Jakarta.

Surat Edaran Bank Indonesia, No. 13/30/DPNP Tanggal 16 Desember 2011 Perihal Laporan Keuangan Publikasi Triwulan Dan Bulanan Bank Umum Serta Laporan Tertentu Yang Disampaikan Kepada Bank Indonesia. Jakarta.

Tristiningtyas, Vita dan Mutaher, Osmad. 2013. Kinerja Keuangan Bank Umum Syariah Di Indonesia. Jurnal Akutansi Indonesia, Fakultas Ekonomi Universitas Sultan Agung Semarang. Vol.3 No. 2, Hal. 131145, Edisi Juli 2013. 
Undang - Undang,Tentang Perubahan atas Undang-Undang No.7 Tahun 1992 tentang Perbankan. UU No. 10 Tahun 1998. Jakarta.
Widantika, Anggi. 2017. Pengaruh Dana Pihak Ketiga Dan Likuiditas Terhadap Profitabilitas Perbankan Bumn Di Indonesia Periode 2008-2015. Skripsi. Fakultas Ekonomi Dan Bisnis Universitas Lampung. Bandar Lampung. Tidak dipublikasikan. 